\title{
GAMBARAN KADAR LOW DENSITY LIPOPROTEIN (LDL) PADA SISWA-SISWI OVERWEIGHT DAN OBESITAS DI KOTA MANADO
}

\author{
${ }^{1}$ Christoffel Elim \\ ${ }^{2}$ Damajanty H. C. Pangemanan \\ ${ }^{2}$ Siantan Supit \\ ${ }^{2}$ Vellisia Lindo \\ ${ }^{3}$ Sarah M. Warouw
}

\author{
${ }^{1}$ Bagian Ilmu Kedokteran Jiwa Fakultas Kedokteran Universitas Sam Ratulangi Manado \\ ${ }^{2}$ Bagian Fisiologi Fakultas Kedokteran Universitas Sam Ratulangi Manado \\ ${ }^{3}$ Bagian Ilmu Kesehatan Anak Fakultas Kedokteran Universitas Sam Ratulangi Manado \\ Email: yantipangemanan@yahoo.com
}

\begin{abstract}
Low-density lipoproteins (LDL) are lipoproteins that carry cholesterol to maintain the functions of cells. One factor that can raise the levels of LDL is obesity. In general, obese people have higher triglycerides stored under the skin (subcutaneous). Triglycerides are the main ingredient for the formation of VLDL in the liver. This study aimed to get an overview of the levels of LDL in overweight and obese students at the Pax Christie and Don Bosco junior high schools in Manado. This was a cross sectional analytic study. Samples involved 30 students meeting the inclusion criteria: age 10-15 years, Body Mass Index (BMI) $\geq 23.0$, and willing to be respondents with signed parental informed consents. Results: Samples of obese students were $26(86.7 \%)$ and of overweight students four (13.3\%). There were six students (20\%) who had LDL higher than normal levels ( $\geq 130 \mathrm{mg} / \mathrm{dL}$ ). Conclusion: InManado, there were more obese students than overweight students. Some of the students showed LDL higher than normal levels.
\end{abstract}

Keywords: students, overweight, obesity, LDL.

\begin{abstract}
Abstrak: Lipoprotein densitas rendah merupakan lipoprotein yang mengangkut kolesterol ke sel-sel tubuh yang memerlukannya, dimana bila kadarnya berlebih tentu akan berpengaruh buruk terhadap kesehatan. Salah satu faktor yang dapat meningkatkan kadar LDL adalah obesitas. Orang gemuk umumnya memiliki kadar trigliserida yang tinggi dan disimpan dibawah kulit. Trigliserida ialah komponen utama yang membentuk lipoprotein densitas sangat rendah (VLDL) di organ hati. Penelitian ini bertujuan untuk mengetahui kadar LDL pada pelajar tingkat dasar Pax Christie dan Don Bosco Manado yang berat badannya berlebih (overweight) dan yang obesitas. Metode penelitian berupa analisis cross-sectional. Sampel sebanyak 30 pelajar dengan kriteria inklusi: umur 10-15 tahun, Indeks Massa Tubuh (IMT) $\geq 23,0$, dan bersedia mengikuti penilitan. Hasil penelitian memperlihatkan jumlah sampel yang obes sebanyak 26 pelajar (86,7\%) dan yang overwight empat pelajar (13,3\%). Terdapat enam pelajar (20\%) dengan LDL melebihi nilai normal ( $\geq 130 \mathrm{mg} / \mathrm{dL}$ ). Simpulan: Di Kota Manado, jumlah pelajar yang obes melebihi yang overweight. Beberapa di antaranya memperlihatkan kadar LDL melebihi nilai normal.
\end{abstract}

Kata kunci: pelajar, berat badan berlebih, obesitas, LDL.

Obesitas merupakan suatu penyakit multifaktorial, yang terjadi akibat akumulasi jaringan lemak tubuh yang berlebihan, sehingga dapat mengganggu kesehatan. ${ }^{1,2}$ 
Data yang dikeluarkan oleh World Health Organization (WHO) pada tahun 2000 memperlihatkan bahwa obesitas merupakan masalah epidemiologi global yang menjadi ancaman serius bagi kesehatan masyarakat dunia. ${ }^{3}$ Dari hasil laporan beberapa tahun terakhir, obesitas di dunia meningkat tiga kali lipat.

Obesitas sangat menonjol di negaranegara berkembang, termasuk Indonesia. Sekitar $18 \%$ populasi remaja dan lebih dari $35 \%$ populasi dewasa mempunyai berat badan berlebihan (overweight) atau obesitas. Dari perkiraan 210 juta penduduk di Indonesia pada tahun 2000, jumlah penduduk yang overweight diperkirakan mencapai 76,7 juta $(17,5 \%)$ dan pasien obesitas berjumlah 9,8 juta (4,7\%). Persentasi ini semakin meningkat dari tahun ke tahun., ${ }^{4,5}$

Himpunan Studi Obesitas Indonesia (HISOBI) melakukan penelitian terhadap 6.318 orang pada tahun 2003-2004 mendapatkan nilai Indeks Massa Tubuh (IMT) dan lingkar perut yang tidak berbeda jauh dari yang diusulkan WHO Western Pacific (Asia Pacific Criteria). Peningkatan prevalensi obesitas di Indonesia berhubungan dengan mudahnya mendapat makanan yang tersedia (siap saji). ${ }^{1}$

Di Sulawesi Utara khususnya kota Manado terdapat banyak orang yang masih beranggapan bahwa makan merupakan hobi dan kegemukan merupakan suatu tanda kemakmuran, terlebih lagi ditambah dengan porsi makan yang banyak dan faktor risiko yang dapat terjadi akibat peningkatan kadar LDL seperti aterosklerosis, hipertensi, diabetes melitus dan stroke. Melihat prevalensi yang cukup tinggi hingga mencapai $80 \%$ pada anakanak obes, yang juga akan mengalami obesitas pada saat dewasa, maka penulis tertarik untuk mencari tahu lebih lanjut tentang kadar LDL pada remaja dengan overweight dan obesitas.

\section{OBESITAS}

Obesitas berasal dari kata latin yaitu ob yang berarti akibat dari dan esum yang berarti makan. Obesitas dapat didefinisi- kan sebagai akibat dari pola makan yang berlebihan. ${ }^{3}$ Obesitas terjadi bila besar dan jumlah sel lemak bertambah pada tubuh seseorang. Jaringan lemak merupakan depot penyimpanan energi yang paling besar. Jaringan lemak tidak hanya dapat merugikan, tetapi dapat juga berfungsi untuk menyimpan energi dalam bentuk trigliserida, membangun jaringan tubuh, melindungi organ tubuh, mencegah tubuh kehilangan panas, dan melarutkan vitamin tertentu. ${ }^{1,2}$

Untuk menentukan obesitas maupun berat badan ideal dapat digunakan beberapa cara, yaitu dengan pengukuran antropometri:

A. Pengukuran berat badan (BB)

B. Pengukuran berat badan dibandingkan kuadran tinggi badan $\left(\mathrm{BB} / \mathrm{TB}^{2}\right)$.

Dikatakan obes bila $\mathrm{BB} / \mathrm{TB}^{2}>25.0$ (IMT menurut Asia Pasifik). ${ }^{1-3,13}$ Bila nilai IMT telah diperoleh, maka hasilnya dibandingkan dengan Tabel 1.

Tabel 1. Klasifikasi obesitas berdasarkan IMT menurut kriteria Asia Pasifik. ${ }^{1}$

\begin{tabular}{|c|c|}
\hline Klasifikasi & IMT $\left(\mathrm{kg} / \mathrm{m}^{2}\right)$ \\
\hline Underweight & $<18.5$ \\
\hline Normal range & $18.5-22.9$ \\
\hline Overweight & $\geq 23.0$ \\
\hline Pre-obese & $23.0-24.9$ \\
\hline Obese & $\geq 25.0$ \\
\hline Obese class 1 & $25.0-29.9$ \\
\hline Obese class 2 & $\geq 30.0$ \\
\hline
\end{tabular}

Beberapa pemeriksaan yang dilakukan yaitu pengukuran lemak subkutan dengan skinfold thickness (tebal lipatan kulit), pengukuran lingkar pinggang (waist circumference) dan pemeriksaan laboratorium.

\section{Etiologi dan patogenesis}

Obesitas terjadi bila konsumsi kalori lebih banyak dari yang diperlukan dan digunakan oleh tubuh., ${ }^{2,7}$ Meskipun penyebab yang pasti belum diketahui, namun patogenesis obesitas terlihat cenderung 
kompleks, multifaktorial, dan berperan sebagai pencetus penyakit kronis dan degeneratif. Faktor-faktor yang menyebabkan obesitas, yaitu: faktor genetik, lingkungan, psikososial, kesehatan, perkembangan, dan kurangnya aktivitas fisik.

Patogenesis obesitas sangat kompleks dibandingkan dengan pemikiran sederhana tentang ketidakseimbangan antara masuk dan keluarnya energi. ${ }^{5}$ Obesitas merupakan hasil dari ketidakseimbangan antara asupan energi dan pengeluaran energi yang berpuncak pada akumulasi lemak yang berlebihan di jaringan adiposa, hati, otot, pankreas, dan organ lain yang terlibat dalam metabolisme. ${ }^{8}$

\section{Lipoprotein densitas rendah (LDL)}

Darah manusia mengandung lemak yang terdiri dari kolesterol, trigliserida, fosfolipid, dan asam lemak bebas. Kolesterol, fosfolipid dan trigliserida merupakan satu ikatan yang disebut lipoprotein. ${ }^{9-11}$ Oleh karena sifat lipid yang sukar larut dalam lemak, maka bahan ini membutuhkan zat pelarut yaitu suatu protein yang dikenal dengan nama apolipoprotein atau apoprotein. Senyawa lipid yang berikatan dengan apoprotein dikenal sebagai lipoprotein. ${ }^{1}$

\section{Hubungan obesitas dengan low density lipoprotein (LDL)}

Pada obesitas terjadi penumpukan lemak tubuh yang berlebihan. Pada individu dengan overweight atau obesitas sebagian besar penyimpanan lemak terdapat di bagian perut, daerah pinggul, dan paha. Umumnya orang obes memiliki kadar trigliserida yang tinggi dan disimpan di bawah kulit. Trigliserida merupakan bahan utama pembentukan very low density (VLDL) di hati. Berkaitan dengan hal ini, maka obesitas cenderung menjadi penyebab meningkatnya kadar kolesterol total, VLDL, dan LDL. ${ }^{15}$

\section{METODE PENELITIAN}

Penelitian yang dilakukan bersifat survei analitik dengan rancangan cross sectional study. Penelitian ini dilaksanakan di SMP Pax Christi Manado dan SMP Frater Don Bosco Manado.

Sampel penelitian ialah sebagian dari populasi yang memenuhi kriteria inklusi yaitu: usia 10-15 tahun, siswa-siswi dengan IMT $\geq 23,0$ (overweight) dan IMT $\geq 25-29,9$ (obes), bersedia menjadi responden, sehat saat diperiksa, surat persetujuan orangtua, dan informed consent. Variabel penelitian ini ialah: LDL, overweight, dan obesitas.

\section{HASIL PENELITIAN}

Penelitian ini dilaksanakan di SMP Pax Christi Manado dan SMP Frater Don Bosco Manado. Pemilihan sampel dilakukan secara acak dari siswa kelas 1 dan 2 yang diprediksikan masuk kategori overweight maupun obes. Sampel yang memenuhi kriteria inklusi berjumlah 30 orang.

Tabel 2 menunjukkan bahwa sampel terbanyak yaitu yang berusia $\geq 12-13$ tahun sejumlah 13 orang (43.3\%).

Tabel 2. Distribusi sampel berdasarkan kelompok usia.

\begin{tabular}{ccc}
\hline Usia (tahun) & $\mathbf{n}$ & $\mathbf{\%}$ \\
\hline $10-11$ & 5 & 16,7 \\
$\geq 11-12$ & 10 & 33,3 \\
$\geq 12-13$ & 13 & 43,3 \\
$\geq 13-14$ & 2 & 6,7 \\
\hline Total & 30 & 100 \\
\hline
\end{tabular}

Berdasarkan distribusi pada Tabel 3, sampel berjenis kelamin laki-laki tidak ada yang mengalami overweight tetapi terdapat 13 orang $(43,3 \%)$ yang mengalami obesitas. Sampel yang berjenis kelamin perempuan dengan overweight ditemukan sebanyak empat orang (13,3\%) dan yang mengalami obesitas sebanyak 13 orang (43,3\%).

Pada Tabel 4 dapat dilihat bahwa sampel yang memiliki anggota keluarga dengan obesitas sebanyak 28 orang, yaitu sekitar 93.3\% dari seluruh sampel. 
Tabel 3. Distribusi sampel berdasarkan klasifikasi overweight dan obesitas dan menurut jenis kelamin.

\begin{tabular}{clccccc}
\hline \multirow{2}{*}{ Klasifikasi } & \multicolumn{2}{c}{$\begin{array}{c}\text { Laki- } \\
\text { laki }\end{array}$} & \multicolumn{2}{c}{$\begin{array}{c}\text { Perem- } \\
\text { puan }\end{array}$} & \multicolumn{2}{c}{ Total } \\
\cline { 2 - 7 } & $\mathbf{n}$ & $\mathbf{\%}$ & $\mathbf{n}$ & $\mathbf{\%}$ & $\mathbf{n}$ & $\mathbf{\%}$ \\
\hline Overweight & 0 & 0 & 4 & 13.3 & 4 & 13.3 \\
Obes & 13 & 43.3 & 13 & 43.3 & 24 & 86.7 \\
\hline Total & 13 & 43.3 & 17 & 56.7 & 30 & 100 \\
\hline
\end{tabular}

Tabel 4. Distribusi sampel berdasarkan anggota keluarga yang mengalami obesitas.

\begin{tabular}{ccc}
\hline $\begin{array}{c}\text { Anggota keluarga } \\
\text { yang mengalami } \\
\text { obesitas }\end{array}$ & n & \% \\
\hline Ada & 28 & 93,3 \\
Tidak & 2 & 6,7 \\
\hline Total & 30 & 100 \\
\hline
\end{tabular}

Pada Tabel 5 dapat dilihat distribusi sampel berdasarkan jumlah makanan yang dimakan dalam sehari. Dari hasil yang didapat paling banyak sampel mengonsumsi makanan sehari dalam jumlah yang normal (2-3 kali makan/hari), yaitu sekitar 27 orang (90\%). Jumlah makanan yang dimakan dalam sehari ini tidak bisa membuktikan orang yang makan tiga kali sehari bertubuh kurus atau pun obes tanpa ditinjau dari porsi yang di makan setiap harinya.

Tabel 5. Distribusi sampel berdasarkan jumlah makan dalam sehari.

\begin{tabular}{ccccccc}
\hline $\begin{array}{c}\text { Jumlah } \\
\text { makan/hari } \\
\text { (kali) }\end{array}$ & \multicolumn{2}{c}{$\begin{array}{c}\text { Laki- } \\
\text { laki }\end{array}$} & \multicolumn{2}{c}{$\begin{array}{c}\text { Perem- } \\
\text { puan }\end{array}$} & \multicolumn{2}{c}{ Total } \\
\cline { 2 - 7 } & $\mathbf{n}$ & $\mathbf{\%}$ & $\mathbf{n}$ & $\mathbf{\%}$ & $\mathbf{n}$ & $\mathbf{\%}$ \\
\hline 2 & 3 & 10 & 2 & 6,7 & 5 & 16,7 \\
3 & 9 & 30 & 13 & 43,3 & 22 & 73,3 \\
4 & 1 & 3,3 & 2 & 6,7 & 3 & 10 \\
\hline Total & 13 & 43.3 & 17 & 56.7 & 30 & 100 \\
\hline
\end{tabular}

Pada Tabel 6 diperoleh data sampel dengan jenis kelamin laki-laki tersering mengonsumsi dua porsi dalam sekali makan (20\%), sedangkan sampel dengan jenis kelamin perempuan tersering mengonsumsi satu porsi dalam sekali makan $(26,7 \%)$.

Tabel 6. Distribusi sampel berdasarkan jumlah porsi yang dimakan tiap kali makan.

\begin{tabular}{ccccccc}
\hline $\begin{array}{c}\text { Jumlah ma- } \\
\text { kanan tiap } \\
\text { kali makan } \\
\text { (porsi) }\end{array}$ & $\begin{array}{c}\text { Laki- } \\
\text { laki }\end{array}$ & $\mathbf{n}$ & $\mathbf{2}$ & \multicolumn{2}{c}{$\begin{array}{c}\text { Perem- } \\
\text { puan }\end{array}$} & \multicolumn{2}{c}{ Total } \\
\hline $1 / 2$ & 0 & 0 & 1 & $\mathbf{n}$ & $\mathbf{n}$ & $\mathbf{\%}$ \\
1 & 2 & 6,7 & 8 & 26.7 & 10 & 33.3 \\
$1 / 2$ & 1 & 3,3 & 3 & 10 & 4 & 13.3 \\
2 & 6 & 20 & 5 & 16,7 & 11 & 36.7 \\
3 & 3 & 10 & 1 & 3,3 & 4 & 13.3 \\
\hline Total & 12 & 40 & 18 & 60 & 30 & 100 \\
\hline
\end{tabular}

Pada Tabel 7 dapat dilihat, sampel yang suka mengkonsumsi makanan jenis snack sebanyak 21 orang (70\%) dari seluruh sampel, dan sembilan orang (30\%) menyukai makanan jenis junk food.

Tabel 7. Distribusi sampel berdasarkan kebiasaan ngemil.

\begin{tabular}{ccc}
\hline Kebiasaan ngemil & n & \% \\
\hline Junk food & 9 & 30 \\
Snack & 21 & 70 \\
\hline Total & 30 & 100 \\
\hline
\end{tabular}

Tabel 8 menunjukkan bahwa sampel dengan overweight tidak ada yang mengalami berat badan berlebih sejak TK (Taman Kanak-kanak), sementara terdapat 10 sampel (33,3\%) telah mengalami obesitas sejak TK. Berat badan berlebih paling banyak terjadi saat sekolah dasar pada sampel dengan overweight, yaitu lima sampel (16,7\%) dan obesitas 15 sampel (50\%).

Berdasarkan Tabel 9 dapat dilihat bahwa sampel dengan faktor risiko terkena dua jenis penyakit paling banyak dialami sekitar 17 responden (56,6\%); sekitar dua responden $(6,7 \%)$ yang memiliki faktor risiko terkena satu dan lima jenis penyakit; lima responden $(16,7 \%)$ memiliki faktor risiko terkena tiga jenis penyakit; dan 
empat responden $(13,3 \%)$ memiliki faktor risiko terkena empat jenis penyakit.

Tabel 8. Distribusi sampel berdasarkan waktu pertama kali mengalami overweight dan obesitas menurut tingkat pendidikan.

\begin{tabular}{ccccccc}
\hline \multirow{2}{*}{ Pendidikan } & \multicolumn{2}{c}{$\begin{array}{c}\text { Over- } \\
\text { weight }\end{array}$} & \multicolumn{2}{c}{ Obesitas } & \multicolumn{2}{c}{ Total } \\
\cline { 2 - 7 } & $\mathbf{n}$ & $\mathbf{\%}$ & $\mathbf{n}$ & $\mathbf{\%}$ & $\mathbf{n}$ & $\mathbf{\%}$ \\
\hline TK & 0 & 0 & 10 & 33,3 & 10 & 33,3 \\
SD & 5 & 16,7 & 15 & 50 & 20 & 66,7 \\
SMP & 0 & 0 & 0 & 0 & 0 & 0 \\
\hline Total & 5 & 16,7 & 25 & 83,3 & 30 & 100 \\
\hline
\end{tabular}

Tabel 9. Distribusi sampel berdasarkan faktor risiko kemungkinan terkena penyakit.

\begin{tabular}{ccc}
\hline $\begin{array}{c}\text { Jumlah faktor } \\
\text { risiko (angka) }\end{array}$ & $\begin{array}{c}\text { Faktor } \\
\text { risiko (n) }\end{array}$ & \% \\
\hline 1 & 2 & 6,7 \\
2 & 17 & 56,6 \\
3 & 5 & 16,7 \\
4 & 4 & 13,3 \\
5 & 2 & 6,7 \\
\hline Jumlah & 30 & 100 \\
\hline
\end{tabular}

Tabel 10 menunjukkan hasil dari pemeriksaan laboratorium kadar LDL dalam darah.

Tabel 10. Distribusi sampel berdasarkan kadar LDL dalam darah.

\begin{tabular}{cccc}
\hline Klasifikasi & $\begin{array}{c}\text { Kadar } \\
\text { LDL } \\
\text { (mg/dL) }\end{array}$ & $\mathbf{n}$ & $\mathbf{\%}$ \\
\hline Normal range & $60-100$ & 11 & 36.7 \\
Near Optimal & $100-129$ & 13 & 43.3 \\
Borderline high & $130-159$ & 5 & 16.7 \\
High & $160-189$ & 1 & 3.3 \\
Very High & 190 & 0 & 0 \\
\hline Jumlah & & 30 & 100 \\
\hline
\end{tabular}

Sumber kadar normal LDL yang dipakai dalam penelitian ini diperoleh dari http:// www.nlm.nih.gov/medlineplus/ency/article /003495.htm

Dari 30 orang sampel, terdapat 13 orang (43,3\%) yang mendekati garis kadar optimal LDL; 11 orang sampel (36,7\%) yang memiliki kadar LDL normal; lima orang sampel $(16,7 \%)$ yang sudah berada pada garis optimal kadar LDL; dan hanya satu orang sampel yang memiliki kadar LDL tinggi.

\section{BAHASAN}

Pada penelitian ini, sebagian besar sampel berada pada kelompok usia 12-13 tahun. Didapatkan sampel berjenis kelamin laki-laki dengan overweight maupun obesitas lebih sedikit jumlahnya (43.3\%) dibandingkan dengan sampel bejenis kelamin perempuan yang mengalami overweight maupun obesitas (56.7\%). Hasil penelitian ini tidak sesuai dengan penelitian yang dilakukan oleh Frecillia Regina pada tahun 2010 di Kota Manado yang mendapatkan bahwa prevalensi obesitas pada anak yang berusia 9-15 tahun lebih tinggi pada anak laki-laki $(59,1 \%)$ dari pada anak perempuan (40,9\%). Hal ini mungkin disebabkan jumlah anak laki-laki di sekolah lebih sedikit dari anak perempuan. ${ }^{25}$

Pada usia pertengahan biasanya anakanak mempunyai nafsu makan yang baik. Banyaknya makan dan kegiatan yang menuntut energi banyak sehingga pada usia ini berat badan dapat meningkat dua kali lipat. Obesitas dapat terjadi jika energi yang masuk tidak sebanding dengan energi yang dikeluarkan. Perilaku dan kebiasaan makan merupakan salah satu penyebab terjadinya obesitas. Penyandang obesitas ternyata sering berasal dari keluarga yang mempunyai kebiasaan makan dalam porsi besar, frekuensi sering, selalu punya persediaan makanan kecil (ngemil), dan makan diluar waktu makan. ${ }^{26}$

Sebagian besar sampel ditemukan memiliki anggota keluarga yang mengalami masalah berat badan berlebih. Sekitar 93.3\% sampel yang memiliki orang tua dengan obesitas. Hasil ini sesuai dengan hasil penelitian Ayuningsih dan Proverawati di Jakarta pada tahun 2010, yaitu rata-rata faktor genetik berpengaruh sebesar 33\% terhadap berat badan seseorang. Disini dapat dilihat bahwa faktor genetik dalam 
keluarga memiliki peranan yang cukup penting akan terjadinya masalah obesitas.

Jumlah porsi makan yang dimakan responden pada penelitian ini lebih banyak ( $>1$ piring makan) dari orang normal biasanya ( $\leq 1$ piring makan). Sampel dengan jenis kelamin laki-laki lebih banyak porsi makannya dibandingkan dengan sampel berjenis kelamin perempuan. Bukan hanya porsi makan dalam setiap kali makan yang begitu banyak, tetapi jumlah makan dalam sehari juga ada yang berlebih. Terdapat tiga orang sampel yang makannya empat kali sehari dan empat orang sampel yang makan tiga porsi dalam setiap kali makan.

Kebiasaan ngemil juga menjadi kebiasaan yang dilakukan responden di waktu senggang. Responden sering ngemil makanan jenis junk food dan snack. Terdapat sembilan orang sampel yang suka ngemil junk food dan 21 orang sampel suka ngemil snack. Kebiasaan seperti ini merupakan salah satu penyebab terjadinya overweight maupun obesitas. Obesitas dapat menyebabkan penyakit seperti kolesterol, hipertensi, diabetes, penyakit jantung bahkan stroke.

Rata-rata sampel suka ngemil dan makan dengan porsi yang cukup banyak. Selain itu kebiasaan berolahraga dan aktifitas fisik yang kurang setiap harinya dapat mengakibatkan terjadinya overweight maupun obesitas. Itu semua dapat menyebabkan ketidakseimbangan antara energi yang masuk dan energi yang keluar. Energi yang masuk lebih banyak dari energi yang dikeluarkan, hal ini dapat menyebabkan terjadinya obesitas.

Banyak mengonsumsi makanan, terutama makanan yang banyak mengandung lemak seperti daging, keju, susu, yoghurt (tinggi lemak), otak, kuning telur, jeroan, udang, margarin minyak kelapa, santan dan makanan tinggi lemak lainnya dapat memicu meningkatnya kadar kolesterol dalam darah. ${ }^{7-10}$

Pada penyakit kolesterol, kadar LDL dalam darah meningkat melebihi batas normal yang dapat menyebabkan menempelnya lemak pada dinding pembuluh darah. Keadaan ini dapat menyebabkan terjadinya penyempitan aliran darah yang disebut aterosklerosis. Aterosklerosis ini dapat meningkatkan tekanan darah, sehingga penderita juga bisa terkena hipertensi. Kemauan untuk hidup sehat, kedisiplinan dan penggunaan obat tertentu dapat membantu orang dengan obesitas untuk menurunkan berat badannya, sehingga mencegah terjadinya komplikasi obesitas yang lebih berat.

\section{SIMPULAN}

Dari hasil penelitian yang dilakukan di SMP Pax Christi Manado dan SMP Frater Don Bosco Manado dapat disimpulkan bahwa jumlah pelajar yang obes melebihi yang overweight. Beberapa di antaranya memperlihatkan kadar LDL melebihi nilai normal.

\section{SARAN}

Responden yang mengalami overweight atau obesitas disarankan untuk menjaga pola makan dan melakukan olahraga secara teratur. Olahraga teratur dapat membantu menurunkan berat badan berlebih disamping mengatur porsi makan dan gaya hidup sehingga dapat terhindar dari berbagai masalah akibat berat badan berlebih termasuk peningkatan kadar LDL dalam darah beserta komplikasi yang dapat terjadi.

Responden yang mengalami peningkatan kadar LDL dalam darah, sebaiknya mengganti pola hidup menjadi pola hidup yang sehat, hindari rokok dan minuman beralkohol, hindari pemicu yang dapat meningkatkan kolesterol, serta mulailah berolahraga secara rutin dan menjaga berat badan yang ideal.

\section{DAFTAR PUSTAKA}

1. Sudoyo A. W, Setiyohadi B, Alwi I, Simadibrata K. M, Setiati S. Buku Ajar Ilmu Penyakit Dalam. Jilid III. (Edisi Kelima). Jakarta: Departemen Ilmu Penyakit Dalam FKUI, November 2009; Hal.1973-78, 1984-86. 
2. Ayuningsih F, Teviningrum S, Krisnawati I. Cara holistik dan praktis atasi Obesitas. Jakarta: Tim Sarasvati, 2010; Hal.2-3, 7-9, 13-4,16-7, 23.

3. Freitag H. Bebas Obesitas tanpa Diet Menyiksa. Yogyakarta: Media Pressindo, 2010; hal. 10,12-13,2729,54-57.

4. Kompasiana . Obesitas itu berbahaya, tapi juga pilihan [homepage on the Internet]. 2012 [updated $2010 \mathrm{Jan}$; cited 2011 Feb 6]. Available from: http://kesehatan.kompasiana.com/medis /2010/01/31/obesitas-itu-berbahayatapi-juga-pilihan/.

5. Uwaifo GI. Obesity [homepage on the Internet]. 2011 [updated 2011 Jan; cited 2011 Feb 6]. Available from: http://emedicine.medscape.com/article/ 123702-overview.

6. PT Roche Indonesia. Overweight dan obesitas di Indonesia [homepage on the Internet]. 2007 [cited 2011 Feb 6] Available from: http://www.obesitas. web.id/pub-obind.html

7. Arumdati S. Cara pintar mengelola Kolesterol Menuju Hidup Sehat Bebas Kolesterol. Yogyakarta: Parasmu, 2009; hal.37, 60-1.

8. Kujang Media. Cara Mudah Menurunkan kadar kolesterol. Kujang: Diandra Primamitra Media, 2009; hal.13,19,3233,46 .

9. Hardjono. Awas Kolesterol (Cetakan Ketiga). Yogyakarta: Maximus, 2009; hal. 10,12,37-38,46.

10. Deviana. Kolesterol: solusi tepat mengelola kolesterol. Yogyakarta: Cemerlang, 2010; hal.9,14-15,77.

11. Odelia V. Buku Saku Cara Cerdas melibas Kolesterol. Semarang: Ega Acitya, 2011; hal.12.

12. Guyton CA, Hall EJ. Buku Ajar Fisiologi Kedokteran (Edisi Kesebelas). Departement of Physiology and Biophysics University of Missisipi Medical Center. Jakarta: EGC, 2007.

13. Hidayati SN, Irawan $R$, Hidayat $B$. Obesitas pada anak [homepage on the Internet]. Nodate [cited 2011 Feb 24]. Available from: http://freedownload books.net/anatomi - fisiologi - lutut doc.htm.

14. Budiman I. Validitas Pengukuran Lemak Tubuh yang Menggunakan Skinfold
Caliper di 2,3,4,7 Tempat terhadap Cara Bod Pod [homepage on the Internet]. 2008 [updated 2008 Feb; cited 2011 Feb 24]. Available from: http://majour.maranatha.edu/index.php/ jurnal-kedokteran/article/view/105

15. Ahima RS. Revisiting leptin's role in obesity and weight loss [homepage on the Internet]. 2008 [cited 2011 Feb 24]. Available from: http://www.ncbi.nlm. nih.gov/pme/articles/PMC2430504/

16. Proverawati A. Obesitas dan gangguan prilaku makan pada remaja. Yogyakarta: Nuha Medika, 2010; hal.70-5,79-83.

17. Wijayanti D. Cara mudah mengatasi problem kolesterol. Yogyakarta: Bangkit, 2009.; hal.32-5.

18. Herliana E, Sitanggang M. Solusi sehat mengatasi kolesterol tinggi. Cetakan ketiga. Tanggerang: Agromedia, 2010; hal.4.

19. Hyperhighs. Lipoprotein Physiology [homepage on the Internet]. 2010 [updated 2010 Feb; cited 2011 Feb 6]. Available from: http://www.ahealthy dietplan.net/healthy-diet-plan-guide / lipoprotein-physiology-ldl-34.html

20. Khanse S. High Cholesterol Causes [homepage on the Internet]. 2011 [updated 2011 Jan; cited 2011 Feb 24]. Available from: http://mediconweb. com/health-wellness/causes-ofcholesterol .

21. Kinsey. Understanding Obesity Related Disease: High Cholesterol [homepage on the Internet]. 2009 [updated 2009 Apr; cited 2011 Feb 24]. Available from: http://dietsinreview.com/ diet_ column/04/understanding-obesityrelated-disease-high-cholesterol.

22. Fifinella V. Awas bahaya laten kolesterol. Bantul: Azna Books, 2009; hal.22.

23. Adib M. Memahami dan Mencegah Kolesterol. Yogyakarta: Kota Buku Indonesia, 2010; hal.29-33.

24. Budiana.Memahami dampak kolesterol [homepage on the Internet]. 2009 [updated 2009 Jan; cited 2011 Feb 6]. Available from: http://portalsehat. com/2009/01/memahami-dampakkolesterol/

25. Regina F. Perbandingann Kadar Adiponektin dan HSCRP antara anak Obes dan Indeks Masa Tubuh Normal 
S76 Jurnal Biomedik, Volume 4, Nomor 3, Suplemen, November 2012, hlm. S69-76

[Tesis]. Manado: Program Pendidikan Dokter Spesialis-I Ilmu Kesehatan Anak, Fakultas Kedokteran Sam Ratulangi; 2010.

26. Musadat A. Analisis faktor-faktor yang mempengaruhi kegemukan pada anak [homepage on the Internet]. 2010 [cited
2011 Feb 6]. Available from: http:// repositiry.ipb.ac.id/bitstream/handle/12 3456789/43334/Tinjauan\%20Pustaka2010 amu2.pdf?sequence $=13$

27. Tandra H. Langsung Jadi Langsing Strategi Mengalahkan Obesitas. Surabaya: Jaring Pena, 2010; hal.7-8. 